\title{
The Doomed Struggle of Tony Last with the Society and the Individual in Evelyn Waugh's $A$ Handful of Dust
}

\author{
Evelyn Waugh'un Bir Avuç Toz'unda Tony Last'ın Birey ve \\ Toplumla Umutsuz Çarpışması
}

\author{
Cemre Mimoza BARTU*
}

\begin{abstract}
A Handful of Dust (1934), the fourth novel of Evelyn Waugh, deals with the struggles of the protagonist Tony Last in various stages of the twentieth century society. Waugh in this novel illustrates a dark picture of the twentieth century English society and its individuals with the aim of laying bare the "human selfishness and self-delusion" (Ward, 2008, p.679). In general sense, the author directs his criticism towards the various aspects of English social life indicating the pervading decadence in the soul of the individual and modern zeitgeist. Focusing on Tony Last' marriage, social relationships and expedition to Brazil, Waugh delineates the portrait of an innocent man who values the past and its traditions. Yet, in order to survive in the society Tony embarks on a quest for self-identity but fails in each attempt. Coinciding with the time of the author's own personal tragedies, the novel also revolves around some certain autobiographical parallelism that Waugh suffered from. As a means of critique of the society and its members, he juxtaposes himself with his character Tony Last to demonstrate their struggle. So as to illustrate Tony's futile attempts in his struggle, Waugh writes two different endings for the novel, both of which end in utter failures. Therefore, by virtue of individual failures and socio-cultural corruption, the novel is concerned with the struggle of Tony Last who is surrounded by those individual, cultural and social adversities. In this study, the modernist theme of the quest of the individual will be analysed through Tony Last's quest in social and personal spheres by also demonstrating Waugh's critique of the modern times.
\end{abstract}

Keywords: Evelyn Waugh, A Handful of Dust, Modernist Novel, Quest, Individual vs Society, Tony Last.

Öz

Evelyn Waugh'nun 1934 yılında yazdığı Bir Avuç Toz, başkahraman Tony Last'ın yirminci yüzyıl Londra'sındaki farklı sahnelerde mücadelesini konu alan yazarın dördüncü romanıdır. Bu romanda Waugh yirminci yüzyıl İngiliz toplumu ve bireyinin karanlık tarafını resmederken "insanın bencilliği ve kendini kandırması" fikrini açıkça ortaya koymaya çalışmıştır (Ward, 2008, p.679). Genel anlamda, yazar modern zamanın ve bireyin ruhunu etkisi altına alan yozlaşmayı ele alarak eleştirisini İngiliz toplumsal yaşamının farklı açılarına yöneltmiştir. Tony Last'ın evliliği, sosyal ilişkileri ve Brezilya'ya yaptığı seyahatine odaklanarak, Waugh geçmişe ve geleneklere değer veren masum Tony Last portresi çizmiştir. Ancak, böylesi bir toplumda yaşamında devam edebilmek amacıyla Tony kendini bulmak için girdiği mücadelelerde her seferinde mağlup olur. Yaşamındaki kişisel trajedilere aynı zamana denk düşen romanda Waugh kendisinin de muzdarip olduğu bazı otobiyografik paralelliklere yer vermiştir. Toplumu ve üyelerini eleştirinin bir yolu olarak, yazar kendisini yarattığ 1 karakter Tony Last yaşadıkları ortak mücadeleleri yansıtmak için karşılaştırma yapmıştır. Mücadelesindeki sonuçsuz girişimleri resmetmek amacıyla da Waugh romana başkahramanın hüsranıyla biten iki farklı son yazar. Bireysel başarısızlıklar ve sosyo-kültürel yozlaşmadan ötürü roman, kişisel, kültürel ve sosyal tersliklerle çevrelenmiş Tony Last'ın savaşı ile ilgilidir. Bu bilgiler ışı̆̆ında, bu çalışmada modernist bir tema olan bireyin arayışı Tony Last'ınki üzerinden incelenirken, Waugh'nun romanındaki modern zamanlar ve kişilerin eleştirisi de tartışılmaktadır.

Anahtar Kelimeler: Evelyn Waugh, Bir Avuç Toz, Modernist Roman, Arayış, Birey ve Toplum, Tony Last.

A Handful of Dust (1934) is the fourth novel of Evelyn Waugh which deals with the struggles of the protagonist Tony Last in various stages of the twentieth century London society. A Handful of Dust, as Wasson states, comments on "the decline of the aristocracy and the fall of the innocent" represented in the high-society of London and it is a palpable critique of the "the whole tradition of the English religious and social life" (1961, p.327). Waugh, in this novel, illustrates a darker picture of the twentieth century English society and its individuals with the aim of laying bare the "human selfishness and self-delusion" (Ward, 2008, p.679). In this respect, the author also directs his criticism towards various aspects of English social life indicating the pervading decadence in the moral values of the individual and modern zeitgeist. Therefore, the novel is concerned with the struggle of Tony Last who is surrounded by the individual, cultural and social adversities. In the light of this information, the modernist theme

* Arş. Gör. Hacettepe Üniversitesi, İngiliz Dili ve Edebiyatı Bölümü, cemrebartu@gmail.com.

Bartu, C. M. (2019). The Doomed Struggle of Tony Last with the Society and the Individual in Evelyn Waugh's A Handful of Dust, Gaziantep University Journal of Social Sciences, 18(1), 1-12, Submission Date: 02-08-2018, Acceptance Date: 22-01-2019.

Araştırma Makalesi. 
of the quest of the individual will be analyzed through Tony Last's quest in social and personal spheres by also demonstrating Waugh's critique of the modern age and its people. Due to Waugh's vexed feelings about modernism and modern times, alienation from the society and self, social and individual struggle, a critique of modern society constitute the chief subject matters of his works. Correspondingly, important critical sources written on his novels focus on these themes; such as A. Clement's work The Novels of Evelyn Waugh: A Study in the QuestMotif approaches the protagonists quests in the novels, William J. Cook, Jr.'s Masks, Modes, and Morals: The Art of Evelyn Waugh also deals with the characters from his early and late novels. Jonathan Greenberg's "Was Anyone Hurt? The Ends of Satire in A Handful of Dust" examines Waugh's understanding of modernism and modernity and his perception about modern London as a spiritual wasteland is also elaborated in Jean Ward's "The Waste Sad Time: Evelyn Waugh's A Handful of Dust." Drawing on Waugh's opinions about modernism as a decadent time phase, this study takes on the social satire and also underlines the personal tragedies of the author that propelled him to give voice through fictionalization.

Having his protagonist Tony Last experience individual tragedies along with the fraudulence in culture and humanity, Waugh explains the focal point of his novel as follows: "A Handful of Dust, my favourite hitherto, dealt entirely with behaviour. It was humanist and contained all I had to say about humanism" (as cited in McDonnell, 1988, p.73). Drawing on the author's own perception of humanism, Lobb explains that the novel is the "analysis of the bankruptcy of a humanism cut off from its religious roots" (2004, p.142-3). For Waugh, an individual's alienation from religion and moral values diminishes his/her concern and common sense for the other people around him/her. In this context, Waugh assumes a pessimistic stance in his novel in writing the drab picture of his distorted perception of humanism, that is to say the human affection and respect. In this novel, he voices his critical reflections on contemporary society by means of the poor quality of the intricate series of relations among the socialites of London. From a wider perspective, it is possible to remark that in A Handful of Dust Waugh sticks to the past and the traditions obsessively, and according to Greenberg "Waugh's attitudes toward both modernism and modernity more generally are similarly vexed" (2003, p. 351). Correspondingly, Waugh's disapproval of the new culture and tradition can clearly be detected in the novel through Tony Last. Hence, this disapproval of the represented new order of the novel is so pervasive that it even had an important role in the title of the work.

The novel starts with an excerpt from T.S. Eliot's The Waste Land from which the title of the novel is taken and also it ends with the same image illustrating the corrupt situation of the novel's world as a "spiritual wasteland" (Ward 2008, p. 695). The characters, who are susceptible to change, waver and decay by means of a small temptation, are nothing but just a handful of dust. Similar to Eliot's Wasteland, Waugh's wasteland is eventually created by modernity and degenerate lifestyle. As a result, what the characters have or-find themselves to be-, a remaining dust of the past and values that modernity has burnt down. If the Wasteland is the break away from the past and the old values, therefore it is created by its denizens, the highsociety of London. Yet, Tony Last, who is exposed to this spiritually barren environment, combats against the contemporary decadence both in social and individual levels.

Given the use of autobiographical elements that he suffered from in his personal relations, it is possible to read Tony' struggle as Evelyn Waugh's reaction towards the moral disintegration. Specifically, his approach to the Bright Young People is explicitly exemplified not only in A Handful of Dust, but also in Vile Bodies (1930) and Brideshead Revisited (1945) where he portrays the condition of London in the first half of the twentieth century along with the undertones of corruption, apathy and false priorities of the characters. Waugh was closely in touch with many members of Bright Young People, who were the renowned figures of London/Mayfair scene in the 1920s inter-war years, and consisted of "small group of artists, 
writers and socialites" famous for their flamboyant lives, "outrageous antics, all-night parties, high speed treasure hunts" in the city (Maloney, 2010, p. 20). One of the contemporaries of America's Jazz Age movement, Bright Young People devoted their time and some part of their lives to sheer enjoyment. They treated London as their playground and performed their extravagant pastimes within the bounds of their financial possibilities. The social relationships among the members rested on the reciprocal hypocrisy and gossip which emphasize the overall issue of spiritual corruption. Although Waugh was not a member of the group, he stayed rather close to observe them meticulously. Waugh considered that "English smart society, despite its surface brilliance, corrupt and decadent. Something is wrong-the traditional standards of value no longer seem to apply. Not morality, but immorality pays" and the outcome of his observations justified of his ideas about these socialites and the social structure, (Nichols, 1962, p. 55). Parallel to the social reality of the period, Waugh's depiction of society in this novel is closer to its actual condition. What Waugh suffered from in his own life is more or less projected in Tony Last's painful experiences with the society and individuals. Basing his novel on these experiences, Waugh, on the background, illustrates a dark picture of the modern times and the novel functions as a criticism of the period with its people. In other words, closer inspection of the modern culture of the twenties, coalesced with Waugh's new religious directions shapes the bleak trajectory of the novel. Additionally, one of the significant reasons that shaped Waugh's conservative stance towards modernism and his perception of humanism is his conversion to Catholicism.

On 29 September 1930, four years before the publishing of A Handful of Dust and a year later his divorce from his first wife Evelyn Gardner, Waugh converted into Catholicism. Since he was a prominent writer of the age, his conversion created a scandalous reaction in the media. Although Waugh stayed quiet on the topic for a short time "the opinion still commonly maintained among his acquaintance, that he became Catholic to compensate himself for the emotional wound he had received on the break-up of his marriage" (Skyes, 1975, p.105). However, Skyes also contends that the reason for his conversion is not supported by any evidence. Even though the break-up was not the chief reason for his conversion, it left such an effect on Waugh's life and his perception of morality that he inserted this break-up story into $A$ Handful of Dust. In order to clarify his motivation in his reception into the Roman Catholic Church, Waugh, on October 20th, 1930's Daily Express, published an essay entitled "Converted to Rome: Why It Has Happened to Me" (Worner, 2016, para. 3). In his expository essay, Waugh explains the reasons why he has converted and also rejects the baseless claims of his detractors as follows:

\begin{abstract}
Today we can see [the loss of Christian faith]... as the active negation of all that western culture has stood for. Civilization - and by this I do not mean talking cinemas and tinned food, nor even surgery and hygienic houses, but the whole moral and artistic organization of Europe - has not in itself the power of survival. It came into being through Christianity, and without it has no significance or power to command allegiance. The loss of faith in Christianity and the consequential lack of confidence in moral and social standards have become embodied in the ideal of a materialistic, mechanized state... It is no longer possible, as it was in the time of Gibbon, to accept the benefits of civilization and at the same time deny the supernatural basis upon which it rests...
\end{abstract}

That is the first discovery, that Christianity is essential to civilization and that it is in greater need of combative strength than it has been for centuries. (Worner, 2016, para.6-7)

The ideas about civilization, moral and social issues penned in the essay established the basis of his novel A Handful of Dust. For that reason, what he voices in his essay is his complaint about the contemporary superficial society. Moreover, his shelter into Catholicism can be regarded as a way of solution and salvation from dishonesty. Merging his discontent with the keen observation of the society, Waugh delineates his modern public in the novel deriving from 
the real condition of the time. Practicing what he preaches, his subsequently published work also functions as a fictional background of his weariness and opinion about developing corruption in social and individual levels.

The modern society depicted in the novel is run by the selfish motives and dishonesty of the characters. However, the primary concern of the society is the financial issues that render the rich more cautious about their status and the poor more ambitious to better their life quality (Littlewood, 1983, p.95). Since vested interest is at the root of the society, the characters from different classes assume appropriate stances in accordance with their own profits or plots they are planning to. For example, at the outset of the novel, the dialogue between relatively less rich Mrs. Beaver and her son John Beaver discloses the order of the social system which depends on self-seeking. In their dialogue, Mrs. Beaver, who is an interior designer, talks about a recent fire break out in one of the houses by giving details about the condition of the house after the fire as follows;

The fire never properly reached the bedrooms I am afraid. Still they are bound to need doing up, everything black with smoke and drenched in water and luckily they had that old-fashioned sort of extinguisher that ruins everything. One really cannot complain. The chief rooms were completely gutted and everything was insured. . . I must get on to them this morning before that ghoul Mrs. Shutter snaps them up (Waugh, 1934, p. 7)

However, when Mrs. Beaver's tone of voice and her choice of expressions are considered, it can be suggested that her real motive in telling the accident is not to commiserate the loss of the family but to make a profit out of an agony by redecorating their house. Her choice of words expresses her real ideas about the accident, hence she feels content about the calamity for it is going to provide her a financial income. As one of the typical unscrupulous characters of the novel, Mrs. Beaver also demonstrates the overall condition of the society in microcosmic level. Her lack of sympathy and avarice can be observed in the society and in the other characters of the novel, apart from Tony Last. Therefore, social parasitism, feeding on the wealth or the fame of others for selfish ends, proves itself to be the rule of the society in the novel. Each one of the characters in the novel is so much engrossed in their own "appetite and inclinations" that the world they live in is consisted of "shallow little characters who have no consequence because they have blandly resigned themselves to live in a treacherous world without hope of recourse to any effective moral order" (McCartney, 1987, p.78). Accordingly, because of the tendency of the characters toward dishonesty the society seems to be unable to find a remedy for its problems and Waugh in this novel only reports the condition of the social and individual tragedies without suggesting any solution or way of reconstruction.

In order to highlight the condition of London society and its people in the twenties, Tony Last and the Victorian values he trusts are juxtaposed with the ones of the new age. Tony Last, as his name suggests is the last person in the novel who values the old tradition and heritage. He is devoted to his country house, although he knows that it is not convenient for him to finance its upkeep. Hetton Abbey is a grandiose building located in a fictional London countryside where Tony's ancestors lived. Nevertheless, the house which was rebuilt in 1864 in Gothic style by the ancestors of Tony "is now devoid of interest" (Waugh, 1934, p.17). The gothic style of the abbey, in fact, hints at the obsoleteness of the building as an architectural style yet, the connotations it carries such as rootedness, old tradition, and lineage. At the time when people begin abandoning "their tradition-laden homes for the chromium-plated apartments" (McCartney, 1987, p.80), Tony adheres to his traditional abode.

The houses in the novel are the symbols of the mind-sets of the characters, and their attitude towards them signifies their tendencies towards the meanings they seem to carry. For instance, Tony's deep interest in an old and traditional building like Hetton emphasizes his over-sensibility for the old Victorian values. Yet, the fact that the house was razed and rebuilt 
implies the change in the English values in that the former ones fall into oblivion while the new ones are constructed upon the old ones. On the other hand, Hetton also represents the "errors of the Victorian imagination" (Wasson, 1987, p.137) which cause its renovation and the corrupt status of the twentieth century society that fall into disgrace because of its former notable condition in the past. Tony's voluntary attachment to Hetton is one of the reasons for his obliviousness towards the realities of daily life. His true adherence to the old values and heritage becomes a major preoccupation of Tony in that, according to Lobb, Tony develops "an adulterous relationship" with Hetton and this "causes him to neglect his wife and son and thus [it] contributes to Brenda's decision to have an affair" (2003-2004, p.131). In fact, Brenda signals her boredom in marriage and life in Hetton through her wish of renovating her outdated Arthurian legend decorated bedroom, which recalls the rooted legend and its ancientness, into a modern one. However, his obtuseness about daily life and "refusal to face facts" (Lobb, 200304, p.132) make him turn his face to Hetton, the past and tradition to avoid the change and the new system. This voluntary ignorance of Tony creates an illusion for himself to feel happy, yet it is indeed a defense mechanism for him to proceed. Cunningham contends that "much of his happiness derives from his illusion about Hetton Abbey; every glazed brick, every encaustic tiles Hetton is dear to Tony's heart" (1993, p.118). Thus it can be suggested that Hetton is an alibi, through which Tony creates the illusion of happy and aristocratic life that he leads without any problem.

For Cunningham, his wife Brenda has been another illusion of Tony until their divorce (1993, p.118). Although in the beginning of the novel Brenda and Tony are depicted as "preeminently successful" pair "getting along well together" (Waugh, 1934, p.27), the personal tragedy of Tony starts with the shattering of his marriage. Given the autobiographical elements of the novel, Tony, in a way shares the same fate with Waugh in terms of unsuccessful marriage and betrayal. Waugh deliberately delineates a perfect wealthy family with a loving couple and a small child in order to show the greatness of the irony he employs. However, Tony's obsession with Hetton triggers Brenda's boredom. Despite their different personalities, they stayed married for eight years. Tony's occupation with Hetton constrains him from partaking in glamorous London society. He judges these London sprees and socialites as low and worthless for he feels superior to the London high-society due to his aristocratic background. Whereas, Brenda desperately craves to be the part of the London highlife which will enable her to socialise and get away from Hetton. With the unexpected visit of John Beaver to Hetton, the established norms of the house are turned upside down and it makes Brenda realise her stranded position in the massive mansion. Upon the question of Beaver whether she likes Hetton, Brenda pours out her real opinions as follows:

\begin{abstract}
Me? I detest it... at least I don't mean that really, but I do wish sometimes that it wasn't all, every bit of it, so appallingly ugly. Only I'd die rather than to say that to Tony. We could never live anywhere else, of course. He's crazy about the place [...] As it is we support fifteen servants indoors, besides gardeners and carpenters and a night watchman and all the people and odd little men constantly popping in to wind the clocks and cook the accounts and clean the moat, while Tony and I have to fuss about whether it's cheaper to take a car up to London for the night or buy an excursion ticket... I shouldn't feel so badly about it if it were a really lovely house- like my home for instance. (Waugh, 1934, p.38)
\end{abstract}

Being a "lazy, scrounging son under his mother's influence" John Beaver sets off for Hetton only for the sake of his "commercialized relationships" and to upgrade his lesser socialite position in London by getting himself moved up in the social ladder (Ward 2008, 6812). Although his motivation is not to entice Brenda but to have a name in the society, he inadvertently deviates Brenda from her roles as a wife and mother by arousing her interest in himself. The more frequently Brenda departs for London, the deeper she succumbs to the high lifestyle of Londoners and her liaison with Beaver. Influenced by the lustre of London society 
Brenda transforms herself into an active socialite by spending most of her time in London and committing adultery without any pang of remorse. Adultery is one of the vital forces of the upper-class Londoners; since it "is not a sin or even an indiscretion," most of the female characters of the novel either yearn for it or experienced it before. Secondly, money and statusoriented society enables Mrs. Beaver to let her flats as pied-a-terre for the adulterous affairs, it also gives John Beaver a new status in London and provides the other characters with new gossip for (Davis "Introduction" 2000, xx). The society is run by the commercialized relationships which dominate familial and social spheres. The influence of money on the characters is so powerful that even six-year-old John Andrew, Brenda and Tony's son, is class conscious. When he is having a small argument with his nanny he calls her "Silly old tart" (Waugh, 1934, p.24) knowing that the nanny earns her living by babysitting him. In the next conversation with his father about the very issue, Tony reminds him what his nanny has been doing for him and his comeback for the question is "She's paid to" (Waugh, 1934, p.25). As the novel unfolds, the decadence of the London society becomes evident. And John Andrew, as someone from the next generation, "is aware of his social status" and "openly express[es] the snobbery of his class, where the adults are hypocritically more discreet" (Ward, 1987, p.683) in their dealings. Even though the clandestine dealings of the characters, such as committing adultery, renting a secret house in the city, gossiping, striving to be counted as a member of the Bright Young People do seem to be related to the social hypocrisy, they all stem from simple financial self-seeking. Hence, corruption caused by the power of money and the decadence both in individual and social levels can be regarded as the epidemic in the society.

In the background of social and individual debauchery, obtuse Tony becomes the scapegoat of the society which is inflicted with its adversaries. By means of the major tragedies of the death of his son and the betrayal that befalls him, Tony's obliviousness is transformed into insight where he grapples with the immoralities of the society and people. In addition to this transformation, his awakening to the realities surrounding him is the point where his real quest of self begins. Similar to the other modernist protagonists such as Ford Madox Ford's John Dowell in The Good Soldier and Christopher Tietjens in Parade's End, Tony can be blamed for his downfall because of his naïve and trustworthy disposition and also he is the victim of his illusion. Moreover, excessive tolerance is his another faulty side and before Waugh "embodie[s] tolerance in the character of Tony Last" (Heath 1983, 108) he condemns it as lenity as follows: "It is better to be narrow-minded than to have no mind, to hold limited and rigid principles than none at all" (as cited in Heath, 1983, p.108). Deriving some of his source materials from his own life in the novel, Waugh employs his first marriage as a pattern of the betrayal between Tony and Brenda. Making an autobiographical reference to his unsuccessful marriage with his first wife Evelyn Gardner, Waugh directly presents his own misfortune in the novel as Tony's. Bearing semblances with Brenda Last, Evelyn Gardner Waugh begins spending much of her time in London and the marriage between he- Evelyn and she- Evelyn (as Waugh himself calls) is threatened; for John Heygate, a friend of theirs, becomes her lover and eventually "she-Evelyn told her husband that she was in love with Heygate and that they had had an affair" which leads to their divorce in the end (McDonnell, 1985, p.11). The decadence of the individual and the society is in such a reciprocal relationship that the more people invigorate it with their wrongdoings, the more London becomes a ground for hypocrisy. While Waugh is criticising the hypocrisy of London society, he also emphasizes that it is the agony of innocent individuals that matters in the novel since they are the ones who are exposed to the vileness of the society which promises no human salvation. Therefore, as Waugh himself writes in the Preface to his alternative ending for A Handful of Dust, the novel is written on the theme of "betrayed romantic" which prioritizes the plight of the soul rather than the society (Waugh, 1934, p. 243). 
As mentioned above, Bright Young People were the quintessential representations of the age with their lifestyle and social circles. In line with this fact, Waugh portrays Brenda and her friends, coquette Polly Cockpurse, eccentric princess Jenny Abdul Akbar, greedy Mrs. Beaver and their affluent parties, shopping routines, luncheons to express the condition of the society. However, Tony's unconditional surrender to Brenda's lifestyle and tolerance to her indifference towards her family strengthen the gravity of the situation. Thus, the point where Tony's quest begins is also the breaking point of the novel where the two opposite sides of the quest is determined: Tony versus Brenda and the corrupt situation of London. The things that Tony has to deal with are closely connected with the depravity of the society that spoils people and it is also the depravity of people that renders the society unscrupulous. Thus, this situation can conspicuously be seen in Brenda's reaction to her son's death. At Hetton, there arranged a hunting party in which John Andrew also takes part under the supervision of the groom Ben. When John is sent back to home on his pony, he is knocked off his pony and falls into the ditch where he instantly dies. Having informed Tony Last about the tragic incident, Jock GrantMenzies goes to London to find Brenda to inform her about John Andrew's unexpected death. But meanwhile, Brenda is already restless about her lover John Beaver's well-being who earlier leaves for Paris. When Jock tells her that John is dead, she is shocked by the news. Only after Jock explains the hunting party at Hetton she comes to a full realization that it is his son John Andrew who is dead, not John Beaver. Later on, she articulates her subconscious revelation unwittingly as follows "John...John Andrew...Oh thank God..." (Waugh, 1934, p.119). After the death of John, Brenda reveals her relationship with John Beaver and wants a divorce from Tony. In relation to Brenda's double-dealing Beaty suggests that the members of the London society both make an effort to "deceive others, unknowingly delude themselves or inadvertently betray their nefarious designs" (1992, p.95). Hence, Brenda is victimized by her own faulty blurting out her real feelings and in the future, she will be victimized by the society that is abusing her. When she is short of money, John Beaver threatens her with break up, Mrs. Beaver refuses to give her a job and Jenny Abdul Akbar insinuates her husband's well-off condition without giving any solace in her misery.

During his quest, Tony always feels that he is under the attack of both Brenda and the expectations of the society. He becomes part of a false plot of cheating on Brenda in order to enable her to sue him for the divorce. Due to his dignified attitude, Tony and Milly, the prostitute he hired to play the role of a mistress, do not even sleep in the same room but only eat together in the restaurant of the hotel to show people his supposed infidelity. Having lost his son and betrayed his principles with the false plot, this time Tony is forced to face the possible loss of his only belonging Hetton when Brenda's brother Reggie comes to haggle about the alimony she will receive after the divorce. Yet, the amount of money she demands is rather high for Tony so, this means he will be obliged to sell Hetton in order to compensate for his loss. Up until this moment in the novel, Tony has always preserved his tolerant and decent attitude towards everyone, especially to Brenda, however when the only thing he depends upon is at stake he assumes a different attitude and for the first time he defends himself by speaking out his upper-hand situation for the issue of divorce:

\footnotetext{
Brenda is not going to get her divorce. The evidence I provided at Brighton isn't worth anything. There happens to have been a child there all the time. She slept both nights in the room I am supposed to have occupied. If you care to bring the case I shall defend it and win, but I think when you have seen my evidence you will drop it. I am going away for six months or so. When I come back, if she wishes it, I shall divorce Brenda without settlements of any kind. Is that clear? (Waugh, 1934, p.153).
}

Mentioning his journey for the first time, the reason for Tony's departure from London to South America is explained in the novel as follows "... he wanted to live for a few months away from people who would know him or Brenda, where there was no expectations of meeting 
her or Beaver or Reggie St Cloud at very corner he frequented" (Waugh, 1934, P. 161) and this in mind he decides to embark on a journey to Brazil with Dr. Messinger to escape. The title of the chapter, "In Search of a City," is also suggestive referring to the fact that Tony is escaping from the troubles in his life by going to an unknown place. This expedition can also be accepted as a practical manoeuvre of Waugh to "strip his hero of all his Gothic illusions" (Clement, 1994, p.105) and come to terms with himself while he is searching for it. Moreover, in order to be successful in his spiritual quest Tony is supposed to get rid of the habits and values of his old self to gain a new one. Thus, his discovery of his wife's moral degradation along with that of the society is only the first step of this change. As a further move, he needs to be "cured of his romantic dreams such as his attachment to the old decrepit Hetton Abbey" and staunch belief in Victorian ideals (Clement, 1994, p.105). In addition to his spiritual quest to transform himself, Tony in his struggle will discover the true meaning of civilization compared to that of London in terms of its decadence and problematic account. Leading indifferent lives in London, the socialites are unaware of the condition of the other nations and judge them with the values of materially civilized England. When Brenda asks Jock about Tony's safety in Brazil Jock's answer, "Oh I imagine so. The world is civilized now, isn't it?- charabancs and Cook's $\mathrm{s}$ offices everywhere" (Waugh, 1934, p.175) demonstrates the ignorance of these figures about the other's lives and their false comparisons.

Set off to escape from London, Tony in his quest reaches the land of Macushi people in British Guiana. In the country, he gets prepared for a long journey to Pie-Wie land with Dr. Messinger, an explorer whom he met during his journey. After a long journey on foot, having guided Tony Last and Dr. Messinger, indigenous Macushi people leave the two at night because of the lack of communication between them and more importantly because of the enmity between Pie-Wies and Macushies, they fear to go into their land. Given the title of the chapter, Tony is in some ways like an Arthurian knight who is after the Holy Grail. Nevertheless, although he knows the reason why he left London, he is ignorant of what he is looking for in the Amazon forest apart from his own self. For that reason, in his spiritual quest he is an "illequipped [soul] to be the questing knight" (Lobb, 2003/2004, p.138) as Heath suggests "[u]nlike the pure knight of legend, who is guided by faith, Tony does not seek the right goal, and he does not know the right questions. Rather than freeing the maimed king, he becomes one of the denizens of the wasteland, waiting for a release that never comes" $(1983, p .120)$. Thus, not only his spiritual journey is interrupted by disorientation of his soul but also his physical health deteriorates because of their helpless condition in the forest. The companions are left in a destitute condition in the sheer wilderness and they are also physically troubled by the foreign climate and geography. Tony's continual hallucinations and fits of fever control the pace of the journey and he gets unable to move because of the lack of stamina. So, Dr. Messinger is compelled to leave him behind to bring a help for Tony, yet he dies on the way.

Wandering around in his demented and unconscious situation, Tony is found by Mr. Todd, a mulatto residing in Pie-Wie land. This part of the novel is, in fact, Waugh's short story entitled "The Man Who Liked Dickens" which was written before A Handful of Dust. Thus, it can be suggested that Waugh, by inserting the story into the novel, writes the story of Tony from the end to the beginning. Mr. Todd, whose name means death in German, carries Tony to his house and heals his delirium with the herbal drink he prepared. Under the ironic appearance of the situation, the help of Mr. Todd is actually the death notice of Tony since his help carries ulterior motives that serve his personal benefit. This benefit that Mr. Todd is trying to acquire is to make Tony read him Charles Dickens' novels, which happen to have been in his house for years. Although the initial depiction of Todd shows him as a man of benevolence, his sinister and darker aspects are implanted in the story in "subtle hints" of the narrator displaying "his promiscuous siring of Indians, his use of shotgun to control them, his knowledge of harmful as 
well as beneficial herbs, and his obsession with Dickens" (Beaty 1992, p.99). With the undertones of colonial mind, Mr. Todd takes his position of being mulatto in the environment for granted and establishes a small one-man empire in the wilderness. Besides his mistreatment of the native people, he acts like a tyrant and Tony also gets his share from his tyrannical attitude. This attitude of him is also observed in his making Tony read Dickens' novels. Though it sounds like an innocent wish of a forlorn man in the forest, later it transforms into a forcible activity he demands every day. According to Greenberg, Mr. Todd's house in the desolate land can be recognized as the place of uncanny where the "barbarism of wilderness" is juxtaposed with the "savagery of civilization" in London (2003, p.363). Even though Mr. Todd saves Tony's life, he uses his upper-hand to bargain with Tony. Smearing his good deed with a selfish intention, Mr. Todd reveals himself to be no different from the members of the London society. As soon as Tony recuperates, he wants to leave Mr. Todd's house to go back. Though Mr. Todd lets him go wherever he wants, he is well aware of the fact that Tony is not going to be able to survive the forest and die anyway. Therefore he withholds Tony without his consent and Tony is left to make a choice between two deaths: starving in the forest or waiting to die while reading Dickens to Mr. Todd.

The reason why Waugh sketched Mr. Todd as a Dickens lover can be observed in the microcosmic world he built for himself. Although he lives in a small indigenous village with the Indians, he leads another life when he makes someone read Dickens' novels. The plenitude of the characters, stories, and emotions are the only way that connects Mr. Todd with the civilized life out there. He supposes that the Victorian life that Dickens depicted is the civilized life from which he learned many things. Utterly in contrast with the perception of Tony's contemporary life and society, Mr. Todd is infatuated with the idea of this depiction of civilization. While Tony departed from it to find and save himself, Mr. Todd finds his soul in the books, yet lives in a world of fiction. In other words, he feels alive with Dickens and the novels allow him to create a virtual reality to exercise his social skills, emotions, and reactions as if he was one of the characters. Moreover, Waugh's other autobiographical parallelism can also be observed in the act of reading Dickens. Because Mr. Todd tells Tony that he loves the way he reads Dickens for it reminds him of his father's reading. In Greenberg's article, by reading Waugh's autobiography, he propounds that Dickens reading was an activity that his father loved to do, especially to his family and friends. Correspondingly, as Greenberg puts "Dickensian scene of domestic novel-reading curiously anticipates (or echoes) Tony's encounter with Mr. Todd" (2003, p.370) where Dickens plays a connecting role between fact and the fiction. This assumption can also be linked to the seemingly nostalgic and romantic atmosphere of Mr. Todd's house supported with an autobiographical anecdote. However, it also highlights the opposite, the uncanny reality of Tony's situation where he is trapped into a homely but creepy locality.

In the official last chapter of the novel, Waugh employs "cinematic narrative technique" (Ward 691) through which the story of the characters in London is recounted in small accounts like the snapshots from their daily lives. Accepting that Tony died in Brazil, Hetton is inherited by his cousins, the last representatives of the Lasts. Teddy Last, who replaced Tony as the master, at the end of the novel aspires to "restore Hetton to the glory that it had enjoyed in the days of his cousin Tony" (Waugh, 1934, p.228). On the other hand, a symbolic tombstone of Tony is erected in the garden to commemorate his name and efforts at Hetton. While the Lasts do pay respect to Tony and follow his footsteps in governing the estate, Brenda proves her fickle disposition by marrying Jock Grant- Menzies who was Tony's close friend. Despite the fact that Tony died in his escape from all the decadence in individual and social levels, in the last portrayal of Hetton and the high-life of London circle nothing seems to change after his death. Hetton is still on the verge of grasping its former glory and the other characters whom 
indirectly or directly caused Tony's downfall retain their lifestyle in London. Thus, in this ending of the novel, Tony seems to be defeated in his quest of himself and the others. Failing in finding the essence of his soul and getting trapped in a situation where he waits for his death, Tony, as the hero of his story cannot rescue himself from the struggles which determine his inevitable death.

Twenty-nine years after the publication of the novel, Evelyn Waugh writes an alternative end to the novel in which Tony comes back from Brazil safe and sound. Associating Tony's expedition with his own trip to Boa Vista in 1933, Waugh explains the reason for this alternative end to the novel as a sheer curiosity and a practical literary manoeuvre which gets his novel published without the ending of his short story "The Man Who Liked Dickens" but with a new one he penned (Waugh, 1934, p.250). In this version of the ending, Tony does not die but somehow succeeds to travel back to England, on the day of his return Brenda comes to pick him up from Southampton with the driver. Leaving her flat in London, she moves back in Hetton and as can be understood in their relationship, there is not any resentment between Tony and Brenda. Their first day together carries not much of distinctive quality than their other days in the past because of the apparent indifference of Tony towards Brenda and Hetton. His careless attitude is observed in his falling asleep in the car at their first meeting after his long journey and his falling asleep for the second time when Brenda tells him about what happened between her and John Beaver. His weariness towards London circle and his wife Brenda is illustrated by his apathetic attitude. Yet, the most significant issue that portrays the new disposition of Tony is his secret agreement with Mrs. Beaver about a flat he wants to keep in London. Behaving like Brenda, Tony wants to keep the same flat in London for himself. Mrs. Beaver, who is always on the relentless money pursuit, confirms Tony's idea to keep the apartment by calling it necessary (writer's italic) (Waugh, 1934, p.250). Thereupon, Tony reflects his ideas as follows:

'Exactly. Well I think I shall keep it on. The only trouble is that my wife is inclined to fret a little
about the rent. My idea is to use it when I come to London instead of my club. It will be cheaper
and a great deal more convenient. But my wife may not see it in that light...in fact...'
'I quite understand'
'I think it would be better if my name didn't appear on that board downstairs.' (Waugh, 1934,
p.250)

Taking the hints, Mrs. Beaver, who still is a sordid character, promises him to let the flat and sort out the name issue on the board. Tony, like the other people in his circle, paves the way for his possible adulterous relationships that he will have in London. He seems keen on cheating both Brenda and his former moral principles, thus he takes care of small details to secure himself. Later in the chapter, Tony lies to his wife about the flat issue when he is asked. Similar to Brenda's case, though nothing is stated openly, Tony seems to become just like the other characters he despised and finally succumbed to the system of the age by being a dishonest and indifferent type of man. Getting rid of his former principles and beliefs about order, tradition and integrity, Tony, in his journey to Brazil remoulds himself into a man of the age and opts out fighting against the moral, social and individual degradation of the people of the time.

Turning back to the title of the novel, Waugh's both endings prove that wasteland is populated by the people who are only "handful of dust" that lack solemn disposition. Being the victim of the society and his frailties and weak character, Tony, both in the official and alternative ending, is defeated and cannot perform his duties to designate his stance in the society. In the first version of his end he surrenders to his human side by being afraid of dying miserably and submits to Mr. Todd who promises his future death and in the alternative version he seems to lack the willpower to fulfill the requirements of his quest and opts for the easy way 
to comply with the rules of the age, becoming one of the reckless Bright Young People of Mayfair circle. Since Waugh's displeased attitude towards his period takes its source from autobiographical elements and his overall distrust to the people of the time, he composes a rather drab future for Tony with a total stalemate. Merging his own experiences with fiction, Waugh not only illustrates his hopeless opinions about modernism but also he justifies his opinions through personal incidents. In correspondence with his ideas of humanism in the novel, Waugh deliberately represents a type of society cut-off from morality and common sense to show the inevitability of human salvation and a possible escape from malice. In a broader perspective, A Handful of Dust contemplates upon the unsuccessful quests of the individuals trapped by the corrupt moral values. Upon his failure in his own life, Waugh finds the refuge in Catholicism, yet Tony is not able to do so; hence in the novel, his double-ended failure is presented drearily. All in all, assuming a pessimistic and satiric tone, the novel conflates the individual and social, the innocent and scheming, past and present, order and disorder under the common denominator of the modern plight triggered by the unscrupulousness which pervades into the depths of both the society and the individual.

\section{References}

Beaty, F. L. (1992). The ironic world of Evelyn Waugh: a study of eight novels. DeKalb: Northern Illinois UP.

Clement, A. (1994). The novels of Evelyn Waugh: a study in the quest-motif. New Delhi: Prestige.

Cunnigham, J. (1993). “A Handful of Dust” reconsidered. The Sewanee Review, 101(1),115124. doi : $10.2307 / 27546667$

Davis, R M. (2000). Introduction. A Handful of Dust. By Evelyn Waugh. London: Penguin.

Greenberg, J. (2003). "Was anyone hurt?": the ends of satire in A Handful of Dust. NOVEL: A Forum on Fiction, 36(3), 351-373. doi: 10.2307/1346095

Heath, J. M. (1983). Picturesque prison: Evelyn Waugh and his writing. Kingston-Montreal: McGill-Queen's UP.

Littlewood, I. (1983). The writings of Evelyn Waugh. Oxford: Blackwell.

Lobb, E. (2003/2004). Waugh among the modernists: allusion and theme in A Handful of

Dust. Connotations, 13, 1-2, 130-43. Date of Access: 16.12.2015, http://www.connotations.de/wp-content/uploads/2017/07/lobb01312.pdf

Maloney, A. (2012). Bright young things: life in the roaring twenties. London: Virgin Books.

McCartney, G. (1987). Confused roaring: Evelyn Waugh and the modernist tradition. Bloomington: Indiana UP.

McDonnell, J. (1988). Macmillan modern novelists: Evelyn Waugh. Houndmills: Macmillan.

McDonnell, J. (1985). Waugh on women. London: Gerald Duckworth \& Co.

Nichols, J. W. (1962) Romantic and realistic: the tone of Evelyn Waugh's early novels. College English, 24(1), 46-56. doi: 10.2307/373847

Sykes, C. (1975). Evelyn Waugh: a biography. London: Collins.

Ward, J. (2008). The waste sad time: Evelyn Waugh's A Handful of Dust . English Studies, 89 (6),679-695.doi10.1080/00138380802252909

Wasson, R. (1987). A Handful of Dust: critique of victorianism. J. F. Carens (Ed.), Critical essays on Evelyn Waugh, (133-43). Boston: G.K.Hal.

Waugh, E. (1934). A Handful of Dust. London: Penguin.

Worner, T. (2016). Christianity or chaos: the life-changing choice of Evelyn Waugh. Date of Access:31.07.2018,https://aleteia.org/2016/08/22/christianity-or-chaos-the-life changing-choice-of-evelyn-waugh/

\footnotetext{
${ }^{\mathrm{i}}$ What Waugh means here is Thomas Cook Travel Agency offices.
} 